\title{
LIDIA BIELINIS ${ }^{1}$
}

\section{Academic Reflective Practice: Tools Supporting the Self-Evaluation Approach}

\begin{abstract}
The aim of the text is to analyse author's own reflective research practice and to give an account of a few exemplifications of tools supporting the self-evaluation process of own academic work, carried out under a case study strategy. Contemporarily, the process of empirical material collection and analysis can be supported by various computer-assisted technologies. The article attempts to present their employment in the self-evaluation approach and the value they have when they are used in qualitative inquires.
\end{abstract}

Keywords:

case study, data collection tools, evaluation, self-evaluation, reflective practice

\section{INTRODUCTION}

The self-evaluation approach has been relatively comprehensively presented and described by researchers (Brzezińska, Brzeziński, \& Eliasz, 2004; Macbeath, 1999; Macbeath \& McGlynn, 2002; Macbeath et al., 2003; Mizerek, 2010; Mizerek, 2017a; Simons, 2009). Nevertheless, data collection procedures can be nowadays carried out with various computer-assisted technologies, enabling a researcher to reach people who can provide information on self-evaluation subject and at the same time ensuring the interlocutors' anonymity. The computer-assisted technologies and applications can also support research analysis as well as empirical data collection. This text sought to analyse own research practice and to present the role

1 Faculty of Social Sciences, University of Warmia and Mazury in Olsztyn, Poland. E-MAIL: lidia.bielinis@uwm.edu.pl ORCID: https://orcid.org/0000-0002-7727-6385 
of various tools supporting the self-evaluation approach implemented in the case study strategy. It is assumed here that strategies and techniques for data collection employed contemporarily by researchers may be supported by tools and applications that give deeper insight into the self-evaluation process of own academic work. Hence, in the first part of the text the main focus is given to the rationale behind evaluation derived from the concept of the fourth generation evaluation (FGE) (Guba \& Lincoln, 1989), in which dialogue is a core category (Mizerek, 2017a, p. 133). It is based on assumptions of constructivist paradigm (Patton, 2015, pp. 272-273; Guba \& Lincoln, 1989, pp. 44-45). The second part is intended to give a deeper insight into own reflective research practice based on the case study strategy. Such tools as: Google Forms, Mentimeter, and social networking sites, are presented and analysed in the context of the vital role they may play in the process of establishing relationships with Others and improving own work as an academic teacher.

\section{THE TRADITION OF THE FOURTH GENERATION OF EVALUATION}

The considerations undertaken in this text begin with a brief review of the term evaluation. Its understanding or conceptualisation gives food for thought to anyone who finds educational evaluation as a part of pedagogy. It is assumed herein that evaluation, in a broad sense, is a kind of both: practical and critical reflection under the outcomes of past actions as well as reflection on activities that may be undertaken in the future to act or perform more wisely and more valuably (Mizerek, 2017a, p. 22). On the other hand, it is recognised as a specific type of applied social research or even a separate discipline used in, e.g., medicine, economics, political sciences, sociology, and pedagogy. It is therefore advisable to call it a trans-discipline (Mizerek, 2017a, p. 25).

There are a few approaches in the history of evaluation thought. One of them - the typology of the fourth generation evaluation proposed by Egon G. Guba and Yvonna S. Lincoln (1989) - seems to be essential for understanding the line of thought in regard to evaluation presented in the text. Also, the four paradigms introduced by Dona Mertens (2010) may give some deeper insight into dialogueoriented evaluation, which is carried out within the framework of the constructivist paradigm. Many scholars' works were significant in the process of bringing the assumptions of constructivist paradigm into evaluation (Guba \& Lincoln, 1989; Patton, 2015; Stake, 1983). 
E.G. Guba and Y.S. Lincoln, for example, identified four generations of evaluation, which are: first generation (measurement-oriented), second generation (description of educational effects), third generation (judgement-based), and fourth generation (based on the constructivist models). The first three of them are carried out within the framework of the positivist paradigm, where it is assumed there is an objectivity to be captured and an objective truth or world that can be measured, described, and verified. The fourth one, called sometimes a dialogueoriented evaluation or the constructivist one, transformed the role of evaluators from technicians, experts, and judges (who know better than subjects participating in evaluation) to participators and facilitators of multivoice reconstruction. The fourth generation of evaluation provides for all voices of people engaged in the evaluation process to be heard in favour of common welfare (Guba \& Lincoln, 1989, p. 110, 1994, p. 112). The ontological, epistemological, axiological as well as methodological rationale behind constructivist paradigm respect the multiple constructions of reality (sometimes they are in conflict with each other) due to assumption that reality is socially constructed. It is also assumed that a researcher and participants are interactively linked, and they are constructing the reality through co-interpretations of data provided by participants (Guba \& Lincoln, 1994; Mertens, 2010). This means that the accountability of the conducted inquiry is shared by each stakeholder and this also results in taking responsibility for evaluation outcomes by all of them.

Moreover, this approach stands in opposition to evaluations oriented for getting on the right side of a customer - due to the dominance of market-based discourse. Also, it contradicts discourses like evidence-based practice or gold standard approaches, which are quite common, and seems to be growing in popularity nowadays (Mizerek, 2017a, p. 35). The knowledge accumulated within the constructivist framework does not perform the conditions of economy discourses and - at the same time - does not provide any evidence-based outcomes. As Guba and Lincoln argue, it is more like forming and transforming provided constructions, so they are varying and becoming more informed and more sophisticated each time. The process of transferring knowledge from one setting to another is possible due to provision of vicarious experience, often presented in case studies reports (Guba \& Lincoln, 1994, p. 114). One of the models, developed as a result of embedding evaluation in constructivist paradigm rationale, is responsive evaluation introduced by Robert Stake (see: Mizerek, 2017a, pp. 38-39) whose works are frequently associated with the case study strategy (Stake, 1994; Simons, 2009; Merriam, 1998; Yin, 2009; Mizerek, 2017b). 


\section{ACADEMIC REFLECTIVE PRACTICE IN THE CONTEXT OF SELF-EVALUATION AND QUALITATIVE RESEARCH}

The issue of reflective practice is comprehensively explored in pedagogy by many researchers (Dewey, 1933; Gołębniak, 2001; Marcos, Miguel, \& Tillema, 2009; Mezirow, 2000; Mitchell, 2017; Mizerek, 2017a; Perkowska-Klejman, 2019; Schön, 1983).

Notwithstanding the many lines in considerations of reflective practice, the most corresponding one with the presented analysis is the study developed by Donald A. Schön (1983). Many works in the fields of pedagogy, teacher studies, and evaluation were written on the basis of his proposition. As regards evaluation, reflection concerns the value of undertaken actions. Nevertheless, two types of reflection were meant in D.A. Schön's work. These were: reflection-on-action (the know-how implicit in the performance), and reflection-in-action ('thinking about doing something while doing it') (Schön, 1983, pp. 54-55). Schön compares a man who reflects-in-action to a researcher who becomes acting in the practice context (Schön, 1983, p. 68). His or her thinking is not separated from acting. The way he or she ratiocinates the action is later converted to an action. Schön depicts it followingly: "his experimenting is a kind of action, implementation is built into his inquiry” (Schön, 1983, p. 68). Moreover, he emphasises that reflection-in-action does not have to take place rapidly - it can stretch - "depending on the pace of activity and situational boundaries that are characteristic of the practice" (Schön, 1983, p. 62).

Reflection-in-action can be a part of the self-evaluation study scheme, which differs substantively from both the external and internal evaluation categories. A better understanding of the self-evaluation approach may be reached by distinction analysis between external and internal evaluation. The first one aims at monitoring a school's work by evaluators who are not part of an institution - they are representatives of different agencies, like: personnel, advisers, and inspectors of local or national authorities. These external evaluations may take place on a local, national or international level (Macbeath \& McGlynn, 2002, pp. 16-18). In turn, the internal evaluation derives from self-interest of those who have a direct stake of a school performance. These are: school's staff, pupils, and parents. Nonetheless, their observations are not free of subjectivity or inactive - they are interested in the welfare of their schools (Macbeath \& McGlynn, 2002, pp. 14-15). As Henryk Mizerek claims, internal and self-evaluation differ by virtue of, e.g., subject of the evaluation, data collection methods, forms, and recipients of the delivered results (see more: Mizerek, 2017a, p. 189). Self-evaluation is rather a specific form of 
the internal one, which is carried out inside institutions and conducted by people sharing two roles, e.g., a role of a class teacher and an evaluator of own practice (Mizerek, 2017a, p. 188).

For the purposes of this text, the term self-evaluation is considered as a process of collecting and communicating information to determine values of the undertaken actions, in which a teacher is positioned in the context of studying her own practice (Mizerek, 2010, p. 23). Additionally, it is assumed here that the process of collecting data can be assisted by computer technologies. These application programs can support the process of constituting own professionalism, which is another complex issue comprehensively discussed, among others, by Bogusława D. Gołębniak (Gołębniak \& Zamorska, 2014). Therefore, some researchers argue that the self-evaluation approach should be employed in a qualitative research model, e.g., in a case study strategy. Helen Simons gives a few examples of evaluation research using case study strategy (see more: Simons, 2009, pp. 59-61, 141-143).

H. Mizerek argues that casual understanding of evaluation corresponds to reflective thinking in the view of asking questions about the value of undertaken actions. Reflective thinking results in reflective acting. However, if a researcher considers evaluation as a specific type of applied social research supplying information, then reflective action is settled in reflection-in-action (Mizerek, 2017a, pp. 108-109). Additionally, a researcher has a specific propensity (reflexivity) enabling him or her to shape methodological awareness (Mizerek, 2017a, p. 121) or even more - to develop one's observer skills, called contemplative approach (Giorgino, 2014). The reflexivity may also provide an evaluator with the knowledge affecting wise, reflective actions and also with the knowledge derived from personal experiences gathered as a result of performing professional tasks (Mizerek, 2017a, p. 123). It is assumed here that both reflection-in-action as well as reflexivity are essential for conducting self-evaluation in the case study strategy.

\section{BACKGROUND TO THE CASE STUDY - OWN ACADEMIC REFLECTIVE PRACTICE}

\section{RESEARCH DESIGN}

This part of the text portrays the author's own experiences and the tools supporting the process of own work evaluation. Herein, all issues are planned to be shown on the basis of conducted research project entitled "Experiencing the Digital Space in the Learning Process of Young Adults”. The project is designed 
to be a qualitative study carried out in the case study strategy. It is assumed that young adults are the people aged between 18 and 25-30 years (Strelau, 2003, p. 317). The participants are constantly asked to evaluate different aspects of the University course, during which various elements of the digital space are employed along the classes. The tools available in the digital space also supported the process of collecting data and enabled the researcher to rethink the relationships between and amongst her and university students emerging in the process of improving own academic practice. Herein, the planned evaluation is perceived as an instrument allowing a researcher to consider her work and relations with Others (Lévinas, 1998) through computer-assisted technologies. It is also a question about the value the tools such as: Google Forms, Mentimeter application, and educational-goaled discussion groups on Facebook, may have for the researcher (a practitioner and a teacher at the same time) who is in a relationship with young adults (students perceived as Others).

\section{TOOLS SUPPORTING THE SELF-EVALUATION OF ACADEMIC REFLECTIVE PRACTICE}

The educational-goaled discussion groups established in the social media, such as Facebook, for the students and the teacher where they were able to create a library of subject matter online materials (like PDF articles, etc.), to share interesting links, and to discuss course-related issues were constantly a subject of participatory observation. The observation consisted in peering activities undertaken by groups' members and the role of the researcher/teacher is connected with the role of a group member (Creswell, 2013, p. 195). The observation of the groups allows taking screenshots by using computer software that supports qualitative research analysis (Roger, 2017, pp. 1-7). The researcher can make observatory records concerning own descriptive notes and reflections (Creswell, 2013, p. 197). The notes and written reflections of his/her observations from the field can be also understood as making field notes. Its research potential is comprehensively analysed by Hanna Kędzierska who stands for including the field notes as an exemplary data source for qualitative research. She argues the field notes can be written in memoires, personal diaries or institutional records (Kędzierska, 2016, pp. 335-336).

Below an excerpt of a field note written after a class with students was presented. It involved the first impressions, emotions, and thoughts of the academic teacher after the students decided to establish a group in the social media in the frame of the university course: ${ }^{2}$

2 The field note was translated into English by the author of the article. All following translations from Polish into English were made by the author. 
04.10.2017

I believe the students reacted positively to the idea of establishing educational-goaled discussion group on Facebook. One of them stayed after the class. She informed me she applied for an individual organisation of studies. ${ }^{3}$ She asked me how it was possible for her to receive full course credits if she was not able to actively participate in our discussion group on Facebook due to the responsibilities she had with her little child. I was a bit surprised. Did students assume I was going to check their activity there and monitor it as it would give them some credits? I said I was not going to follow the frequency of her activity in the group and that I was more interested in her reflection of advantages the group in the social media may bring into her learning process and relationships with others there. I was very concerned with her afterthoughts. The students added me as a group member the same day. There were 24 of us... I posted a file with the course program and also a link with an animated tale "The Fantastic Flying Books of Mr. Morris Lessmore". They commented the posts, said: 'thank you', etc. The posts also received some likes. One of the students sent a PDF file with the text for the next class [...]

Source: author's own descriptive field note related to observations of students' reactions and participatory observation of the group in social media, 2017.

The participatory observation also allowed the researcher to reflect-in-action through gaining insight into posts and comments occurring in the discussion group. Some of the posts provoked the breakthrough in relationships between the students and the academic. Some of the participants grew to discuss with the teacher the subject-matter issues as it was a full-partnership. The following post's excerpt (Figure 1) pictured the captured moment of discussion between the two Others: ${ }^{4}$

3 In Polish system of higher education full-time students can try to get individual organisation of studies (indywidualna organizacja studiów, IOS), which is available for these young adults who, e.g., take care of their own child. IOS means they are not obliged to attend all classes but at the same time they have to arrange an individual way of receiving course credits with each academic.

4 The link posted in the discussion group on Facebook triggered a conversation between the student and the academic about the education-related issues. The screenshot presented on Figure 1 shows only a part of the conversation that ran on one day. The teacher posted a link with a short question directed to all group participants: Do you know the Finnish education system? The link was titled: 10 differences between the Polish and Finnish education system.

The student who decided to discuss the link content started with the following statement: It would have been much better for our 'kids' if they were allowed to shape their own 'I' from the beginning, and were not forced to perpetuate schemes and configurations that were preconceived and were not a 'product' of a particular educator. The lack of control, in my opinion, has a positive influence on the process of shaping their 'I' because it does not give a child a sense of fear or fright of being assessed/labelled/derided. There is [in Finland] discretion - from the beginning till the moment of being educated and the individual development is fostered, and I like it :) The candidate selection for pedagogical positions also seems to be a good move there, because not everyone possesses predispositions and we should be aware of that fact. And finally, state-financed teachers' trainings - sounds like a dream :; 
Figure 1. An Excerpt Picturing the Discussion between the Student and the Academic Teacher through a Discussion Group on Facebook

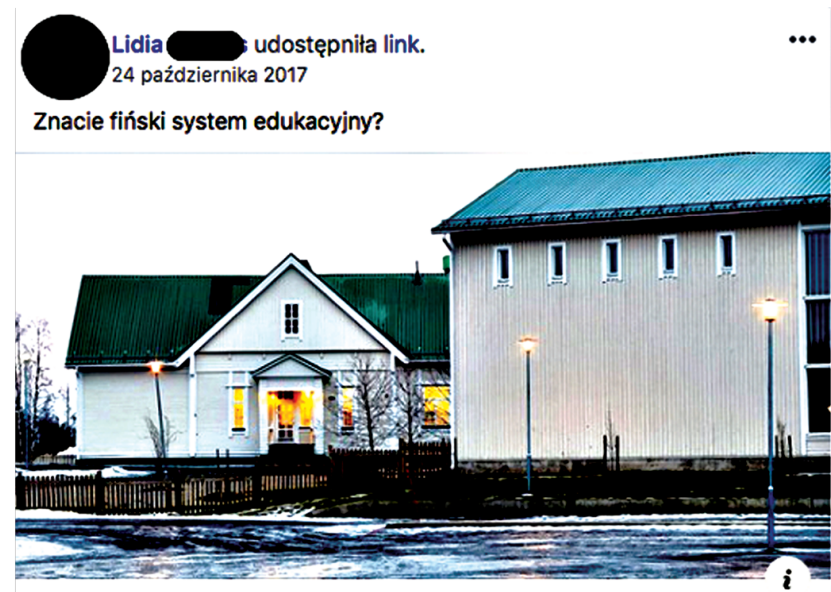

DZIECISAWAZNE.PL

10 różnic pomiędzy polskim a fińskim systemem edukacji

10 różnic pomiędzy polskim a fińskim systemem edukacji -...

6 komentarzy Wyświetlone przez 3

I dla naszych "dzieciaków", byłoby o wiele
lepiej,gdyby od początku mogły kształtować swoje "ja",a nie
trwać w schematach i konfiguracjach z góry założonych, być
"produktem" danego wychowawcy.Ten brak kontroli moim
zdaniem wpływa pozytywnie, bo nie generuje lęku i strachu przed
oceną/etykietką/wyśmianiem.Tu jest dowolność-od początku,aż
po zdobycie wykształcenia wspiera się rozwój jednostek,podoba
mi się to $\because-$ selekcja kandydatów na stanowiska pedagogiczne
wydaje się również dobrym posunięciem,nie każdy ma
predyspozycje i trzeba mieć to w świadomości. I szkolenia
nauczycieli/pedagogów finansowane przez państwo-marzenie
Lubię to! · Odpowiedz · 2 I
Lidia
kształtowanie swojego ,ja", to u nas trudne. Nauczyciele
dysponują sztywnymi, odgórnie przygotowanymi programami
nauczania.
W Polsce trwa aktualnie debata o tym jak sprawić, żeby
uczniowie nie byli „przeładowani" pracami domowymi, podczas
gdy w Finlandii w ogóle nie ma... Wyobrażacie sobie to? Szkoła
bez prac domowych? $\%$

Source: author's own research, 2017.

The teacher responded: I think so, too. However, the issue related to shaping individual 'I' is a little bit difficult in our country. The teachers have the fixed curricula at their commands. Currently in Poland, there is a debate on the subject of overloading pupils with tremendous amount of homework. While in Finland there is no homework at all... Can you imagine this? School without homework? :) 
This exchange of opinions made it possible to start a real conversation as well as threw the two Others open for each other, in the way Emmanuel Lévinas understands it (Lévinas, 1998, pp. 26-27). It was assumed that probably the way conversations were acted - through computer-mediated communication - could influence the relationships.

In the same case study carried out between 2017-2018 students' course, the Google Forms tool allowed collecting data derived from semi-structured Internet interviews (Kozinets, 2012, p. 161). The tool provided time for reflecting upon given answers and the sense of anonymity to participants. In qualitative research models, it is good to reflect on the questions asked. Although a number of questions is unlimited, it is a good practice to think of the area of research interests and prepare a list of open questions. A researcher sees upcoming answers on an on-going basis. He or she can also save each answer or all of them in the PDF file. This is very useful for the further analytical process.

One of the questions included in the interview form concerned the nature of relationships the students had with the academic in consequence of being members of the same group in the social media. The collected empirical material and its interpretation are a testament to an untypical relationship. Several students, to some extent, experienced reframing in their individual frame of reference (Mezirow, 2000, p. 16). Particularly in terms of relationships perception amongst them and the academic teacher:

\begin{abstract}
It was the first time I had an occasion to take part in something like this. My experiences are very positive. The situation demonstrated that you can be in touch with your lecturer and share opinions that are not only related to the course content. The relationship between me and the teacher was far less stressful than usually, the teacher showed interest and was open to my opinions and ideas. Thanks to Facebook, contacts between us were much faster and easier (Gr. 2 St. 4).

The nature of relationships was different than the one I used to experience for years. One of the assets was also the fact we did not have to stand face-to-face with the lecturer, and this reduced the stress level as well as facilitated communication (Gr. 2 St. 5).
\end{abstract}

The issue related to dialogue in the formal education space gives food for thought to anyone who is interested in teachers' studies. As B.D. Gołębniak and B. Zamorska argue, a teacher may be in constant dialogue with himself or herself as well as with Others due to professionalisation process that takes place in educational everyday life between school participants (Gołębniak \& Zamorska, 2014, p. 70). Also, adult education is considered as a formal one (Schugurensky, 2000, p. 1). However, as Mieczysław Malewski argues: 
Educational practices, and adult educational practices in particular, are always wider and less transparent than theoretical models. Hence, formal education is always accompanied with the context of informal learning situations, whose sources are rooted in socio-cultural school environment. Metaphorically speaking, there is always a corridor next to a school class. Non-formal educational institutions can incorporate lots of school curricula elements to their educational course content. Moreover, they are always situated in their own context of informal learning. Finally, knowledge accumulated as a result of everyday living and knowledge that builds individuals' common experiences may reveal in formal and non-formal education, may interact with official educational messages content, it may misshape it, change the range of it, and also reject it (Malewski, 2010, p. 41).

The role of academics also changes significantly as a result of interpermeating of formal, non-formal and informal learning. These adults' teachers transform from knowledge providers into animators of people's life environment, whose role is to facilitate adult learning (Malewski, 2010, p. 43; Chan et al., 2011).

The self-evaluation approach related to providing information about the value of undertaken actions in terms of university course was enriched with partial evaluation of the method used during the classes. There were several attempts of evaluating different aspects of adult education courses (see more: DeLong et al., 2011, Spiel, Schober, \& Reimann, 2006). Herein, particularly, an attempt was made at evaluating the collaborative work on one electronic mind map. Each map was created as a result of two or three previous classes. Students brought their own laptops or tablets (one device for a team of several people), other subject-matter knowledge materials, and they worked on problems, questions or matters that were prepared for them by the academic as a review of few previous classes. This action originated from opinions of former students who asked the academic many times: why academics want us to learn and do projects together if, eventually, they test us individually? The undertaken action was planned to replace the tests, traditionally passed individually by students, and possibly, to trigger collaborativelybased learning. It was believed that this kind of approach to the learning process of young adults may activate different attitudes amongst learners as well as that it may trigger rethinking the relationships amongst students as well as between them and the academic.

The data were collected through short comments of participants on the work with electronic mind map and word clouds of associations the students had with the mind map. The empirical material was gathered right after each class the method was employed at and it was collected through Mentimeter application.

The tool allows collecting various data such as: opinions, short comments, associations related to a word or a picture, and some statistical data. It is freely 
available, and each user of the application can prepare three slides of questions at once, which are free of charge. The application enables also presenting the results of the collected material right after it is finished. It also guarantees the sense of anonymity. The participants use their smartphones and a special code to enter the application. Then they vote, give an opinion or write a comment, which is presented incognito. The researcher, however, is able to see the number of participants who took part in the survey. Figure 2 shows an exemplary slide with students' statements. They were asked to write a short comment on the work with the electronic mind map. ${ }^{5}$

Figure 2. Short Comments Slide Given by the Students on the Work with the Electronic Mind Map during the Review in the Frame of the Course

\section{Please, write a short comment about your work with the mind map. \\ Napisz proszę komentarz dot. Twojej pracy z mapą myśli.}

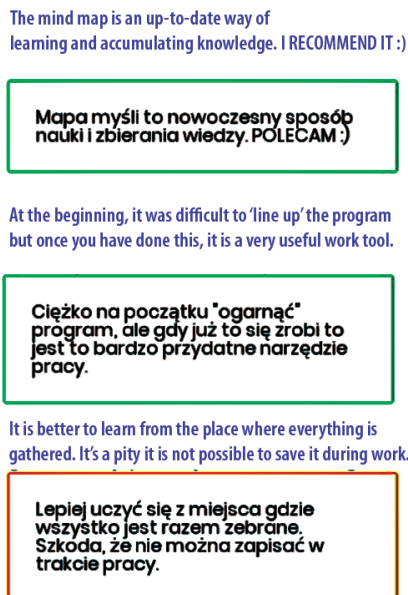

I think it is a very good way of assimilating a large amount of material ;)

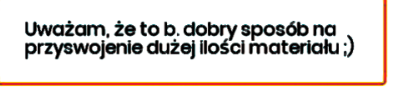

Cool way for collaborative work, exchange of own views on the subject and also for reasonable organisation of different content.

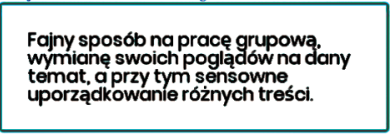

The biggest problem is the fact that some 'clouds' are deleted and it is not possible to undo it

Największym problemem jest to. że kasują się niektóre "chmurki î nie można tęgo cofnąć
The map is a cool way of making a note, however I am not sure if I will use it.

Mapa to fajny sposób na robienie Mapa to fajny sposob na robienie
notatki, ale nie wiem czy z mapy notatki, alen
skorzystam.

Good collaboration in a team, an effective way of learning :)

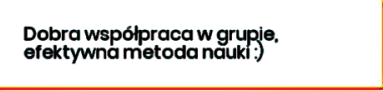

it is quite hard to work on the map due to multitude of functions but it is interesting

dość ciężko się z mapą pracuje ze wzgledu na wielość funkcji ale jest bardzo ciekawa

Source: author's own research, 2018.

Additionally, the other slide presented in Figure 3 portrayed the students' associations related to the electronic mind map.

5 The presented short comments in Figure 2 were translated into English (these are statements written above each original comment of a student). 
Figure 3. Participants' Associations in Relation to the Electronic Mind Map

Please, enter three associations related to the electronic mind map. .

\section{Wpisz 3 skojarzenia związane z elektroniczną mapą myśli...}

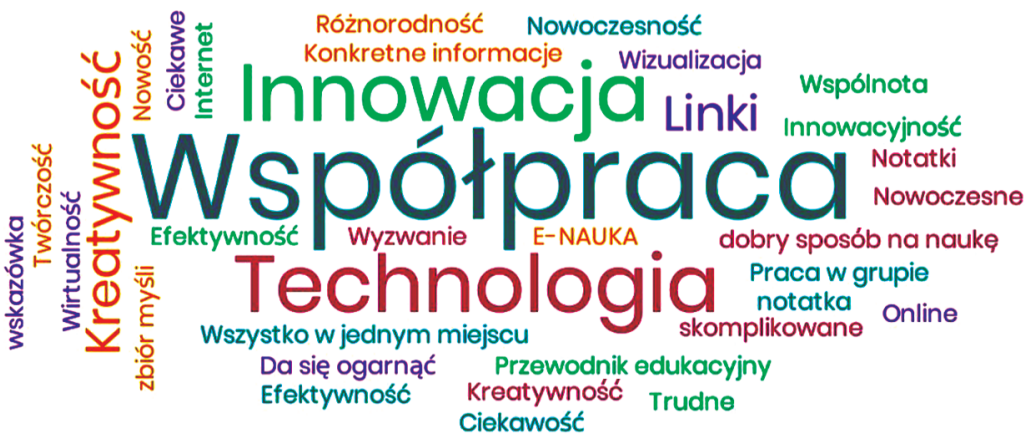

Source: author's own research, 2018.

The word cloud (Figure 3) showed the biggest words or phrases, which means that participants used them most commonly as associations. Additionally, during the analysis process, it was decided to enumerate synonymic words (that were also used by students) in brackets. The most common indicated associations were: 'cooperation’ (community, teamwork), ‘innovation’ (innovativeness, modernity, modern, novelty), 'technology' (links, online, virtuality, e-learning, Internet, visualisation), and 'creativity' (fertileness, variety). There were also a few words mentioning the rough time with the map: difficult, complicated, and a challenge. However, on the other hand, there were also some words indicating: learning, a good way of learning, a collection of thoughts, notes, etc. At this point, it was assumed the student group was more focused on emphasising aspects related to cooperation, what was also observed in the short comments. Nevertheless, the collected data did not say much about the relationships amongst students and between students and the lecturer.

Hence, the study was extended afterwards, and it was planned to collect qualitative papers, represented by reflective, narrative essays written by students that concerned their experiences related to creating the electronic mind maps collaboratively during the classes. C. Kyles and L. Olafson discuss the reflective writing approach. They emphasize that the diversity of personal narrative reflections can uncover hidden assumptions or beliefs of participants and can also lead to collecting more authentic data (Kyles \& Olafson, 2008, pp. 507-509). In respect of reflective writing, the Google Forms tool was employed again. It was assumed in 
the project to collect the essays with one initiatory statement: "Please, describe your experiences gathered during the work with the electronic mind map (think of situations and moments that were significant from the perspective of your learning at the University)". The form was sent to participants at the end of the course and the open-ended statement gave them an opportunity to write borderless, unstructured texts and also to reflect on the time they feel they really wanted to give some feedback to the academic. ${ }^{6}$

Non-traditional form of testing the students' background in the university course had an effect on their longer testimonies related to a matter of contemporary learning process at the University. Three groups of codes: emotional statements, educational advancement and stopping the monotony were interchanging with two other groups of codes, which were called variety of opinions and sources as well as places, spaces and time of learning. The participants' emotions expressed in essays were mainly enjoyment, happiness, and amazement:

Step by step I was learning how to use the software, which made me jolly, and it was mainly the springboard out of our grey, University everyday life (Gr. 1 St. 1).

I really liked leaving the monotony of classes. First lesson resulted in highly positive perception and curiosity (Gr. 1 St. 9).

Participants also emphasised the issue connected with stopping the monotony:

[...] we used the electronic form, which is rarely practised during studies, because most of teachers are rather focused on the traditional forms of learning (Gr. 2 St. 1).

They also indicated educational advancement during assessing the tool. They understood the advancement as combining the educational process with the newest technology. Here is the statement that represents this issue:

The mind map connects education with technology, which is a huge step forward and advancement in our country and in the Polish education at all. Anyone else [...] has not entered me into that model of teaching and conducting classes before (Gr. 2 St. 17).

Furthermore, the participants stressed the fact that education shall be based on creating knowledge through apposing different points of views, opinions and information sources, which took place during our classes with the electronic tool. That experience was raised in majority of participants' essays:

6 The excerpt of analysis of students' reflective essays presented below was previously published in: Bielinis (2018). 
Thanks to that we are able to create a conversation for a specific topic, because each of us has got a distinct opinion, he or she interprets some things/matters in a different way - it is very important (Gr. 1 St. 3).

George Siemens (2005) argued that adult education has its specific rules in connected environment. Some of them are: active participation in the process of learning, extending the scope of knowledge, and using different sources when an individual learns. He also emphasised that in the digital era, the learning process may take place in devices. This issue clearly emerged in the stories of participants. Additionally, they described different spaces, places and time of learning, which are not so obvious nowadays and may not be limited to the University or library building walls:

It was pretty that we were able to modify the map many times and in all places. What you needed was only a mobile phone, and the time of work was not precisely specified (Gr. 1 St. 4).

You do not need to sit at home or in the library, but you may have a look into the map in each free moment - even in a bus on the way to classes (Gr. 1 St. 5).

I mostly liked the fact that we could fill it in at home, during the breaks between classes or in a tram (Gr. 1 St. 8).

The last statement concerned issues related to the cooperation amongst young adults during the classes. The student said: We could fill it in [...], which literally means that she was not doing it just by herself; there were definitely some of them working on the map. The fact of arising cooperation was the most important revelation. Further participants' stories were a testament to two findings: a lot of them were learning the cooperation, and what is more important, they were learning due to cooperation. I presume that probably the first contact with the tool that demonstrated them how to work together could initiate the process of learning the cooperation, and then work teams were learning due to cooperation. Following excerpts of students' stories may depict the fact of learning the cooperation:

We could learn to cooperate. It was not based on the rule 'I am thrown back on myself' (Gr. 1 St. 3).

This form of work realised me that other people who were members of the team had their own opinions and we needed to take them into account (Gr. 1 St. 12).

On the other hand, these statements support the track related to the process of learning due to cooperation: 
The way our map is created intrinsically involves all participants of a meeting, stimulates into thinking, associating, searching for relationships. These are difficult to receive in traditional learning conditions (Gr. 1 St. 10).

We shared problems with each other, and we solved them together (Gr. 1 St. 6).

We could debate on many interesting topics, argue a little bit, but then we developed the best version of the discussed topic together (Gr. 2 St. 24).

Additionally, some of them suggested that I should share the idea of mind mapping and collaborative work with other academics:

I would like other teachers to use that form of testing, because I learn best through the contact with other person (Gr. 2 St. 7).

'It's a pity' describes best many of students' testimonies related to the fact that not many academics (in participants' experience) use new technologies and collaborative work techniques during University classes. This also is a piece of valuable information for the academic who may become aware of necessity of employing specific elements to the course content. The analysed content of narrative essays testifies that it is worth evaluating your own practice, within the meaning of constructing and reconstructing university everyday reality, in a way that scholars termed as dialogue-oriented evaluation. Incorporating participants' voices into the process of reflection also means an academic is on track for becoming a professional. The professional who becomes through a relationship with Others.

\section{ACADEMIC REFLECTIVE PRACTICE - WHY IS IT WORTH EMPLOYING COMPUTER-ASSISTED TECHNOLOGIES TO THE SELF-EVALUATION APPROACH?}

The self-evaluation approach is extensively discussed by many researchers (Brzezińska et al., 2004; Macbeath, 1999; Macbeath \& McGlynn, 2002; Macbeath et al., 2003; Mizerek, 2010; Mizerek, 2017a; Simons, 2009). Depending on the subject of self-evaluation - that the one in the presented case study was own academic practice during the continuance of the University course - researchers are allowed to use various data collection procedures. In the manuscript it was stressed that, contemporarily, the processes of data collection and analysis (aided by various computer-assisted technologies) can support the self-evaluation investigations. There are a few reasons for using them. First of all, they guarantee 
interlocutors' anonymity, which indeed is necessary to carry out the research in terms of professional ethics. Secondly, they allow the investigator to collect data derived from different sources and triangulate them to corroborate gathered findings. Thirdly, their use enables participants to go beyond the time and space. They can complete an interview form, write a short comment, opinion or an essay at any time. As a result of this, empirical material collection process is more flexible. Finally, computer-assisted tools allow the investigator to collect data in parallel with the conducted courses, without the need for an additional research session during which participants are asked to complete evaluation questionnaires, etc. The analysis testified that typicality of the briefly-presented case relied on interrelationships between the course participants and the academic. The academic was capable of becoming a reflective practitioner due to provision of multivoice reconstruction of her own practice. In the presented case, the provision of all voices to be heard was possible due to employment of computer-assisted technologies that supported the process of reconstructing academic own practice. The purpose of the analysis presented in the manuscript was to argue convincingly that the employment of the computer-assisted tools is, on the one hand, an option available for the investigators but on the other hand, a necessary practice to make their explorations more ethical, wise, and valuable.

\section{References}

Bielinis, L. (2018). Why Do You Want Me to Learn Connectively but Test Me Individually?

Socially Embedded Learning at the University. In: V. Lubkina, S. Usca, \& A. Zvaigzne (Eds.), Society. Integration. Education: Proceedings of the International Scientific Conference May $25^{\text {th }}-26^{\text {th }}$. Vol. 1 (pp. 39-56). Rezekne: Rezekne Academy of Technologies. DOI: 10.17770/sie2018vol1.3245.

Brzezińska, A., Brzeziński, J., \& Eliasz, A. (2004). Ewaluacja a jakość kształcenia w szkole wyższej. Warszawa: Wyd. SWPS „Academica”.

Chan, P., Wilkinson, J., Graham, C.R., Borup, J., \& Skeen, J. (2011). Blended Learning: Transforming Teacher Roles in 21 ${ }^{\text {st }}$ Century Education. In: K.W. Loo, \& C.W. Yu (Eds.), 2010 Year Book of the Hong Kong Association for Computer Education (pp. 18-28). Hong Kong Association for Computer Education Press.

Creswell, J.W. (2013). Projektowanie badań naukowych. Metody jakościowe, ilościowe i mieszane. Kraków: Wydawnictwo Uniwersytetu Jagiellońskiego.

DeLong, M., Geum, K.K., Gage, K., McKinney, E., Medvedev, K., \& Park, J. (2011). Cultural Exchange: Evaluating an Alternative Model in Higher Education. Journal of Studies in International Education, 15(1), pp. 41-56. DOI: 10.1177/1028315309334619.

Dewey, J. (1933). How We Think: A Restatement of the Reflective Thinking to the Educative Process. Boston: Heath. 
Giorgino, V.M.B. (2014). Contemplative Methods Meet Social Sciences: Back to Human Experience as It Is. Journal for the Theory of Social Behaviour, 45(4), pp. 461-483. DOI: $10.1111 / j t s b .12078$.

Gołębniak, B.D. (2001). Ku pedeutologii refleksyjnej - od „agresywnej pewności” do „łagodnej perswazji”. Teraźniejszość - Człowiek - Edukacja: Kwartalnik Myśli Społeczno-Pedagogicznej (Numer specjalny), pp. 203-222.

Gołębniak, D.B., \& Zamorska, B. (2014). Nowy profesjonalizm nauczycieli. Podejścia - praktyka - przestrzeń rozwoju. Wrocław: Dolnośląska Szkoła Wyższa.

Guba, E.G., \& Lincoln, Y.S. (1989). Fourth Generation Evaluation. London-Thousand OaksNew Delhi: Sage Publications.

Guba, E.G., \& Lincoln, Y.S. (1994). Competing Paradigms in Qualitative Research. In: N.K. Denzin, \& Y.S. Lincoln (Eds.), Handbook of Qualitative Research (pp. 105-117). Thousand Oaks, CA: Sage.

Kędzierska, H. (2016). Noty terenowe - status, przetwarzanie i potencjał badawczy. Rocznik Andragogiczny, 23, pp. 335-346. DOI: 10.12775/RA.2016.017.

Kozinets, R.V. (2012). Netnografia. Badania etnograficzne online. Warszawa: Wydawnictwo Naukowe PWN.

Kyles, C.R., \& Olafson, L. (2008). Uncovering Preservice Teachers’ Beliefs about Diversity through Reflective Writing. Urban Education, 43(5), pp. 500-518. DOI: 10.1177/00420 85907304963.

Lévinas, E. (1998). Całość i nieskończoność. Esej o zewnętrzności. Warszawa: Wydawnictwo Naukowe PWN.

MacBeath, J.E.C. (1999). Schools Must Speak for Themselves: The Case for School Self-Evaluation. London and New York: Routledge.

MacBeath, J.E., \& McGlynn, A. (2002). Self-evaluation: What's in it for Schools? London: Routledge Falmer.

MacBeath, J., Schratz, M., Meuret, D., \& Jakobsen, L. (2003). Czy nasza szkoła jest dobra? Warszawa: WSiP.

Malewski, M. (2010). Od nauczania do uczenia się. O paradygmatycznej zmianie w andragogice. Wrocław: Wydawnictwo Naukowe Dolnośląskiej Szkoły Wyższej.

Marcos, J.J.M., Miguel, E.S., \& Tillema, H. (2009). Teacher Reflection on Action: What Is Said (in Research) and What Is Done (in Teaching). Reflective Practice, 10(2), pp. 191-204. DOI: $10.1080 / 14623940902786206$.

Merriam, S.B. (1998). Qualitative Research and Case Study Applications in Education. San Francisco: Jossey-Bass.

Mertens, D.M. (2010). Research and Evaluation in Education and Psychology (3 ${ }^{\text {rd }}$ Ed.). Los Angeles-London-New Delhi-Singapore-Washington DC: Sage Publications Inc.

Mezirow, J. (2000). Learning to Think Like an Adult: Core Concepts of Transformation Theory. In: J. Mezirow et al. (Eds.), Learning as Transformation: Critical Perspectives on a Theory in Progress (pp. 3-33). San Francisco: Jossey-Bass.

Mitchell, V.A. (2017). Diffracting Reflection: A Move beyond Reflective Practice. Education as Change, 21(2), pp. 165-186. DOI: 10.17159/1947-9417/2017/2023.

Mizerek, H. (2010). Efektywna autoewaluacja w szkole - jak ją sensownie zaprojektować i przeprowadzić? In: G. Mazurkiewicz (Ed.), Ewaluacja w nadzorze pedagogicznym. Autonomia (pp. 19-62). Kraków: Wydawnictwo Uniwersytetu Jagiellońskiego. 
Mizerek, H. (2017a). Ewaluacja edukacyjna. Interdyskursywne dialogi i konfrontacje. Kraków: Oficyna Wydawnicza Impuls.

Mizerek, H. (2017b). Studium przypadku w badaniach nad edukacją. Istota i paleta zastosowań. Przegląd Pedagogiczny, 1, pp. 9-22.

Patton, M.Q. (2015). Qualitative Research \& Evaluation Methods (4 ${ }^{\text {th }}$ Ed.). Los Angeles-London-New Delhi-Singapore-Washington DC: Sage Publication Inc.

Perkowska-Klejman, A. (2019). Poszukiwanie refleksyjności w edukacji. Studium teoretycznoempiryczne. Warszawa: Wydawnictwo Akademii Pedagogiki Specjalnej.

Roger, K. (2017). The Fringe Value of Visual Data in Research: How Behind Is Academia? International Journal of Qualitative Methods, 16(1), pp. 1-7. DOI: 10.1177/16094069177 36668.

Schugurensky, D. (2000). The Forms of Informal Learning: Towards a Conceptualization of the Field. Working Paper 19-2000. Presented at the New Approaches for Lifelong Learning (NALL) Fourth Annual Conference, October 6-8.

Schön, D.A. (1983). The Reflective Practitioner. How Professionals Think in Action. [New York:] Basic Books.

Siemens, G. (2005). Connectivism: A Learning Theory for the Digital Age. International Journal of Instructional Technology and Distance Learning, 2(1), pp. 3-10.

Simons, H. (2009). Case Study: Research in Practice. Los Angeles-London-Singapore-Washington DC: Sage Publication Inc.

Spiel, C., Schober, B., \& Reimann, R. (2006). Evaluation of Curricula in Higher Education: Challenges for Evaluators. Evaluation Review, 30(4), pp. 430-450. DOI: 10.1177/01938 41X05285077.

Stake, R.E. (1983). The Case Study Method in Social Inquiry. In: G.F. Madaus, M. Scriven, \& D.L. Stufflebeam (Eds.), Evaluation Models (pp. 279-286). Boston: Kluwer-Nijhoff.

Stake, R.E. (1994). Case Studies. In: N.K. Denzin, \& Y.S. Lincoln (Eds.), Handbook of Qualitative Research (pp. 236-247). Thousand Oaks, CA: Sage Publications.

Strelau, J. (2003). Psychologia. Podręcznik akademicki. Vol. 1: Podstawy psychologii. Gdańsk: GWP.

Yin, R.K. (2009). Case Study Research: Design and Methods. Los Angeles, CA: Sage. 